\title{
The Effects of Terrorism on Happiness: Evidence from Turkey
}

\author{
Julide Yildirim \\ Professor \\ TED University, \\ Department of Economics \\ Ankara, Turkey \\ julide.yildirim@tedu.edu.tr \\ phone: 00903125850037
}

\author{
Tekin Kose \\ (Corresponding Author) \\ Assistant Professor \\ TED University, \\ Department of Economics, \\ Ankara, Turkey \\ tekin.kose@tedu.edu.tr \\ phone: 00903125850035
}

Gizem Tanrivere

Research Assistant

TED University,

Department of Economics,

Ankara, Turkey

gizem.tanrivere@tedu.edu.tr

phone: 00903125850193

\begin{abstract}
The economic impacts of terrorism have been extensively examined in the literature. Yet, there is a paucity of empirical research investigating the effect of terrorism on welfare. Existing studies suggest that, in addition to economic costs, terrorism also has social costs. The aim of this paper is to examine the association of terrorism and life satisfaction for Turkey, by utilizing both micro-data at individual level and macro-data at provincial level. In order to address income endogeneity, the conditional mixed process estimation method has been utilized. Estimation results indicate that terrorism hinders happiness. Additional factors such as perceived relative income, gender, employment status and household size have significant effects on happiness levels of individuals. Empirical findings suggest that measuring only economic costs of terrorism fails capture the true extent of the costs imposed on the society. Additionally, single equation ordered probit estimates fail to capture the bidirectional relationship between life satisfaction and income level.
\end{abstract}

Keywords: Terrorism; Happiness; Conditional Mixed-Process Model; Turkey. JEL Codes: D60, I31, R13, C30, O53 


\section{Introduction}

Recent terrorist attacks in Istanbul, Ankara, Paris, Brussels and Nice, and a sharp rise in terrorist activities in Middle Eastern countries and North Africa have created a global concern and distress among many nations. Even though terrorist activities might be localized, the global fear of terrorism affects lives of vast populations, especially in targeted metropoles and big cities. Terrorism has economic, psychological, and social consequences for any country exposed to terrorist events. Even if a country has not been directly affected by terrorism, there could be spillover effects from the neighboring countries and/or trade partners. There are alternative channels through which terrorism may affect an economy. Terrorism may lead to an increase in transaction costs (Frey, Luechinger, \& Stutzer, 2007); a decrease in tourism revenues (Blunk, Clark, \& McGibany, 2006; Brian W Sloboda, 2003; Drakos \& Kutan, 2003; Enders, Sandler, \& Parise, 1992; Yechiam et al., 2005); a decrease in savings (Fielding, 2003); a decrease in number of firms and employment (Greenbaum, Dugan, \& Lafree, 2007) and a decrease in foreign direct investment (Fielding, 2004), that hinder economic progress. The counter terrorism activities entailing an increase in security and military expenditures may have a negative impact on economic growth (Eckstein \& Tsiddon, 2004). In addition to its economic impacts, terrorism also has intangible costs, including the increased levels of anxiety in the society; pain and despair of victims; a reduced life satisfaction and happiness. Turkey has been suffering from terrorist activities for almost fifty years. During these years, Turkey was exposed to both domestic and international terrorist attacks. However, large part of terrorism in Turkey arises from the attacks of PKK, and has a regional context in the sense that the terrorist activities are mainly concentrated in the Southeastern region of the country (Ocal \& Yildirim, 2010; Yildirim \& Öcal, 2013). With intensification of terrorist events in Turkey, claiming many lives and damaging property, Turkish people has been experiencing major interruptions of daily activities such as delayed commuting in metropoles, closed schools, interrupted education, difficulties in access to health services, inconsistent work hours, in addition to a significant amount of stress and fear, which are similar to the experiences reported for Israel (Shalev, Tuval, Frenkiel-Fishman, Hadar \& Eth, 2006). Moreover, fear of terrorism deters people from their daily activities, such as shopping, as they try to stay away from crowded places, leading to a decrease in daily economic transactions. The economic impact of terrorism for Turkey has been examined in the literature. Existing studies agree that terrorism hinders economic growth in Turkey (Araz-Takay, Arin, \& Omay, 2009; Ocal \& Yildirim, 2010). Yet the impact of terrorism on wellbeing of Turkish citizens 
has not been previously investigated. This study aims to explore the impact of terrorism on happiness by utilizing both micro-data at individual level and macro-data at provincial level from Turkey. The micro-data are from Life Satisfaction Survey of 2013 where the sampling enables the researchers to obtain individual level variables. Additionally, provincial level data regarding macroeconomics correlates are obtained from regional accounts/statistics of Turkish Statistical institute. Data relating to terrorist incidents are gathered from the Global Terrorism Database (GTD) of international terrorism incidents. Terrorism index is calculated as averages of incidents, injuries and fatalities occurred in each province. Conditional mixedprocess models are employed for the empirical analysis. Rest of the paper is structured as follows: The next section reviews the literature for the impact of terrorism on well-being of individuals. The third section summarizes the data. Analytical framework and estimation method are presented in section four. The model and estimation results are summarized in section five. Finally, section six concludes.

\section{Literature Review}

In defence economics literature terrorism is generally defined as the premeditated use or threat to use violence by individuals or subnational groups against noncombatants to obtain political and social objectives through the intimidation of a large audience beyond that of immediate victims (Enders \& Sandler, 1993, 2000). Terrorist incidents have ideological, social and political motives. Terrorist activities are carried out to spread fear so that the terrorist can reach their ultimate goals, by forcing the officials and politicians to reach an accommodation with them. Several national and international terrorist organizations have been contributing to terrorism in Turkey. ${ }^{1}$ Since 1980 s until recently the Kurdistan Workers' Party (PKK) was the major terrorist organization in Turkey, which is accompanied by Islamic Great Eastern Raiders/Front, and Turkish Workers' and Peasants' Liberation Army (TIKKO) (Drakos \& Kutan, 2003).

Even though the roots of ethnic terrorism have been attributed to the regional inequalities prevalent in Turkey ${ }^{2}$, unrest in Middle East, especially in Iraq and Syria, has contributed to the escalation of ethnic terrorism in South Eastern Turkey since the early 1990s. There have been attempts to solve the conflict peacefully and the ruling party (Justice and Development

\footnotetext{
${ }^{1}$ Please see Ocal and Yildirim (2010) for a detailed account of terrorism in Turkey.

${ }^{2}$ Please see Feridun \& Sezgin (2008) and Yildirim and Ocal (2013) for the root causes of terrorist incidents in Turkey.
} 
Party) has initiated a peace process in $2009 .{ }^{3}$ Within the framework of the peace (resolution) process meetings between the Turkish National Agency representatives and the PPK leaders have been held in Oslo in 2012, which later came to be known as the Oslo Process. As a consequence of the peace process, there has been a decline in the number of PKK-initiated terrorist events between 2012 and 2013. However, continued terrorism activities on the part of PKK, which is met by military operations by the security forces, interrupted the Oslo Process. After the 2015 elections, PKK terrorism has been escalating with a new strategy of targeting urban areas, especially big cities, rather than the rural areas. PKK claimed the responsibility of the car-bomb attack that took place on February 17, 2016, in Ankara, the capital of Turkey, costing at least 30 lives and 60 fatalities. The elevated political upheaval in Syria and Iraq, leading to the rise of the Islamic State in Iraq and Levant, (ISIL), has proven to be a new source of terrorist activity. The ISIL threat to Turkey became clearer with suicide attacks in Southeastern province of Sanliurfa on July 20, 2015 resulting in 32 deaths and nearly 100 injuries; in Ankara bombing on October 10, 2015, costing 102 lives; and in Istanbul on March 19, 2016, killing 12 people all of which were foreign tourists, in addition to bomb attack on January 12, 2016.

Existing research on Turkey agrees that terrorism hampers economic growth. Araz-Takay et al. (2009) investigate the macroeconomic effects of terror by employing non-linear econometric methods for 1987-2004 periods. They report a large and significant economic impact, which is pronounced during expansionary periods. Ocal and Yildirim (2010), on the other hand, employ provincial level data and perform a regional effect analysis employing geographically weighted regression approach. They report that terrorism negatively affects economic growth across Turkey. However, its adverse effects are more accentuated in the South Eastern provinces, where most of the terrorist activity has been concentrated. Bilgel and Karahasan (2013) explore impact of terrorism on real GDP in the terror stricken Eastern and Southeastern Turkey, for the period 1975 to 2001, by employing the synthetic control method. Their empirical results reveal an average gap of about 7 percent between the actual real GDP of Eastern and Southeastern Anatolia and the real GDP of a comparable synthetic Eastern and Southeastern Turkey in the absence of terrorism. They attribute the estimated gap to PKK terrorism.

Turkey has been a popular tourist destination, attracting more than 25 million foreign tourists in 2016 with total revenue of 31.36 billion US dollars according to recent Turkstat figures. In

\footnotetext{
${ }^{3}$ Please see Ünal (2016) for a detailed account of terrorism activities of PKK and Peace Process in Turkey
} 
2015, Turkey has been the $6^{\text {th }}$ most visited country according to the World Tourism rankings published by the United Nations World Tourism Organization. Tourism sector has been regarded as a source of foreign exchange reserves in the literature, while creating employment and leading to economic growth. In addition to international conflict in the Middle East, international and national terrorism are reported to have a negative impact on tourism revenues (Tosun, Timothy, \& Ozturk, 2003). Accordingly, another strand of the literature examines the impact of terrorism on tourism for Turkey (Drakos \& Kutan, 2003; Yaya, 2009). Terrorist events generally have a long lasting negative impact, even after the reestablishment of the stability (Enders and Sandler, 1991; Enders, Sandler, \& Parise, 1992). Empirical research for Turkey suggests that the negative effect of a terrorist event is observed after 10 months (Yaya, 2009). Drakos and Kutan (2003) examine the issue for three countries in the Mediterranean region with a high incidence of terrorism: Turkey, Israel, and Greece. Their empirical findings support the results from single country studies in that terrorism significantly hampers tourist arrivals. Moreover, terrorist incidents in any country not only affect domestic economy, but also have significant spillover effects on the tourism markets of neighboring countries, leading to regional loss in economic activity.

The effects of terrorism on various sectors and overall economy have been assessed by the researchers. Terrorism leads to an increase in production and transaction costs; a decrease in savings; and a decrease in foreign direct investment. In turn, these all result in a significant cost on the economy which causes reduced economic growth. However, total social and political impact of terrorism is difficult to estimate. Terrorism and counter terrorism policies may have psychological consequences for individuals, impairing daily life of the citizens who are not only directly affected by terrorist events, but also those who are indirectly affected by the terrorist incidents. Post-traumatic stress disorder and depression is common among the individuals who live in the countries exposed to terrorist attacks (Schuster et al., 2001; Schiff, 2006; Canetti-Nisim, Halperin, Sharvit \& Hobfoll, 2009). All of these consequences reduce the welfare of the society (Frey et al., 2007). Yet, there is a lack of empirical research investigating the effect of terrorism on welfare.

Frey, Luechinger and Stutzer (2009) estimate the cost of terrorism on life satisfaction in the regions of France, British Isles and Northern Ireland between the years of 1973/75 and 2002. They report significantly negative effect of terrorism and positive effect of income on life satisfaction. Similarly, Romanov, Zussman and Zussman (2012) study effect of terrorism on happiness of Israelis between the years 2002-2004 (during the Intifada). They reveal the differences in happiness levels of Jewish and Arab Israelis. Although terrorism fatalities does 
not have a significant impact on the happiness level of Jewish Israelis; the authors show that Arab citizens of Israel are not satisfied with their lives due to terrorist attacks. Vorsina et al. (2015) also investigate social costs of terrorism employing cross country data from 117 countries covering the period from 2006 to 2011. They explore the direct relationship between life satisfaction of individuals and terrorism, and the indirect effect of terrorist activities on life satisfaction through its impact on national income. According to Vorsina et al. (2015), terrorist activities directly cause lower life satisfaction. Secondly, terrorist activities reduce national income and then it indirectly reduces life satisfaction.

Previous research on the determinants of life satisfaction in Turkey examine the relationship between subjective well-being and socio-demographic factors (Dumludag, 2013; Dumludag, Gokdemir, \& Giray, 2016; Ekici \& Koydemir, 2014; Selim, 2008). Empirical findings of Selim (2008) reveal that health, income and employment significantly affect happiness and life satisfaction in Turkey. Ekici and Koydemir (2014) reveal the relationship between happiness and different aspects of social capital. Dumludag (2013), (Dumludag, Gokdemir, \& Giray, 2016) and Caner (2014) provide a comparative analysis for life satisfaction of Turkish individuals. Dumludag (2013) find that household consumption level and income have a significant impact on life satisfaction. Caner (2014) suggests that in addition to absolute income, favorable income comparisons enhance the level of happiness in Turkey, while their effects vary with business cycles. Dumludag et al. (2016) and Caner (2014) point out that relative standing of income level is an important determinant of individual's life satisfaction. Moreover, household income, being a housewife, being retired and living in rural areas are positive correlates of happiness. Yet, none of the existing studies shed light on the link between terrorism and happiness for Turkey. Thus, this study aims to complement the literature by exploring the effects of terrorism on happiness in Turkey.

\section{Data and Descriptive Statistics}

The data for this study is obtained from the Life Satisfaction Survey (LSS) conducted in Turkey by the Turkish Statistical Institute (TUIK) in 2013, which was the first LSS to reveal the data at province level. The survey consists interviews with 196,203 individuals aged 18 or over, belonging to 125,720 households. Individuals' answer to the question "Thinking about your life as a whole, how happy would you say you are?" constitutes the self-reported happiness variable. Answers were given on a scale of five (1 completely happy; 5 completely unhappy). In order to be in line with other studies, the answers converted into a scale as 
ranging from 1 completely unhappy; to 5 completely happy. Monthly household income variable consists of 5 response categories, ranging from income of less than $\$ 1,000$ to an income of $\$ 2950$ or more. Additionally, respondents' perception of their own income have also been captured by asking the question "Imagine a 10-step ladder, on the bottom of which, on the first step, stand the poorest $10 \%$ people in Turkey, and on the highest step, the 10th, stand the richest $10 \%$ of people in Turkey. On which step of the ladder are you?', Data relating to terrorist incidents are gathered from the Global Terrorism Database (GTD) of international terrorism incidents. Terrorism index is calculated as the averages of incidents, injuries and fatalities occurred in each province following Eckstein and Tsiddon (2004) and Ocal and Yildirim (2010). During 2013 there had been 37 terrorist incidents in Turkey, resulting in 83 deaths, 38 wounds and property damage. The major incidents include suicide bombing to US Embassy in Ankara, car bomb attack in the Syrian border city of Hatay, which cost 66 lives. The major target sites were schools, military bases, police headquarters, construction areas and government buildings.

Descriptive statistics are presented in Table 2, where happiness variable is grouped into three categories: Happy (completely happy + happy), Neither happy nor unhappy, Unhappy (completely unhappy + happy). The mean happiness score is 3.56 with a standard deviation of $0.86 .60 .32 \%$ of the sample report that they are happy whereas $10.89 \%$ of respondents reveal their unhappiness. Higher proportions of females $(62.05 \%)$ and married $(62.47 \%)$ individuals report that they are happy compared to males (57.96\%) and unmarried (53.45\%), respectively. Youngest and oldest groups of the sample exhibit higher proportions of happy individuals. University graduates have the highest proportion $(62.5 \%)$ as happy individuals whereas illiterate group has the highest proportion (15.8\%) as unhappy. Unemployed people are more likely to be unhappy compared to the employed people. It appears that money brings happiness since percentage of happy people rises as the level of income increases. 
Table 1. Variable Definitions

\begin{tabular}{|c|c|}
\hline VARIABLES & DEFINITION \\
\hline Terrorism Index & Averages of incidents, injuries and fatalities in each province \\
\hline \multicolumn{2}{|r|}{ Individual Variables } \\
\hline Happiness & $\begin{array}{l}\text { Self-reported. Ranges from } 1=\text { "completely happy" to } 5=\text { ="completely } \\
\text { unhappy" }\end{array}$ \\
\hline Gender & $=1$ for Females and $=0$ for Males \\
\hline Age & Age of the individual \\
\hline \multirow[t]{4}{*}{ Education level } & No schooling (Reference Group) \\
\hline & Primary education \\
\hline & High School \\
\hline & University and higher education \\
\hline \multirow[t]{6}{*}{ Work status } & Working or temporarily laid off (Reference Group) \\
\hline & Unemployed \\
\hline & Retired \\
\hline & Permanently disabled \\
\hline & Keeping house \\
\hline & Student \\
\hline Married & $=1$ for Married, $=0$ otherwise \\
\hline Immigrant & $=1$ if the person had migrated in the previous year, $=0$ otherwise \\
\hline Unhealthy & $\begin{array}{l}=1 \text { if the person had serious health problems in the previous year, }=0 \\
\text { otherwise }\end{array}$ \\
\hline Perceived Income & Income ladder. Ranges from 1(lowest) to 10 (highest). \\
\hline \multicolumn{2}{|r|}{ Household Variables } \\
\hline \multirow[t]{5}{*}{ Income Group } & Group $1 \quad 0-1000$ US Dollar \\
\hline & Group $21001-1435$ US Dollar \\
\hline & Group 31436 - 2000 US Dollar \\
\hline & Group $42001-2950$ US Dollar \\
\hline & Group 5 More than 2950 US Dollar \\
\hline \multicolumn{2}{|c|}{ Number of females in the household } \\
\hline \multicolumn{2}{|c|}{ Number of disabled in the household } \\
\hline \multicolumn{2}{|c|}{ Number of students in the household } \\
\hline
\end{tabular}


Table 2. Level of happiness (\%)

\begin{tabular}{|c|c|c|c|}
\hline & Happy & $\begin{array}{c}\text { Neither happy nor } \\
\text { unhappy }\end{array}$ & Unhappy \\
\hline Total & 60.32 & 28.79 & 10.89 \\
\hline Male & 57.96 & 30.40 & 11.63 \\
\hline Female & 62.05 & 27.61 & 10.34 \\
\hline \multicolumn{4}{|l|}{ Age group } \\
\hline 18-24 & 65.1 & 26.8 & 8.1 \\
\hline 25-34 & 60.3 & 30.9 & 8.8 \\
\hline $35-44$ & 55.1 & 33.8 & 11.1 \\
\hline $45-54$ & 54.5 & 33.2 & 12.4 \\
\hline $55-64$ & 58.2 & 28.9 & 13.0 \\
\hline $65+$ & 63.4 & 23.6 & 13.0 \\
\hline \multicolumn{4}{|l|}{ Education level } \\
\hline $\begin{array}{l}\text { Illiterate/not graduated from } \\
\text { primary school }\end{array}$ & 59.8 & 24.4 & 15.8 \\
\hline Primary school & 57.3 & 31.9 & 10.9 \\
\hline Secondary school & 58.4 & 31.9 & 9.7 \\
\hline High School and equivalent & 59.8 & 31.2 & 9.0 \\
\hline University/graduate education & 62.5 & 29.5 & 8.0 \\
\hline \multicolumn{4}{|l|}{ Marital status } \\
\hline Married & 62.47 & 28.01 & 9.52 \\
\hline Not married & 53.45 & 31.28 & 15.27 \\
\hline \multicolumn{4}{|l|}{ Working Status } \\
\hline $\begin{array}{l}\text { Working or temporarily laid } \\
\text { off Employed }\end{array}$ & 59.46 & 31.16 & 9.38 \\
\hline Unemployed & 42.12 & 33.83 & 24.05 \\
\hline Retired & 61.72 & 28.07 & 10.22 \\
\hline Permanently disabled & 44.21 & 28.78 & 27.01 \\
\hline Keeping house & 64.01 & 26.49 & 9.49 \\
\hline Student & 51.04 & 33.23 & 15.73 \\
\hline Unhealthy & 51.33 & 29.85 & 18.81 \\
\hline \multicolumn{4}{|l|}{ Income Groups } \\
\hline $0-\$ 1000$ & 56.42 & 28.82 & 14.76 \\
\hline \$1001- \$1435 & 61.41 & 29.36 & 9.24 \\
\hline \$1436- \$2000 & 61.73 & 30.01 & 8.26 \\
\hline$\$ 2001-\$ 2950$ & 64.59 & 28.93 & 6.47 \\
\hline$\$ 2950+$ & 69.72 & 25.31 & 4.97 \\
\hline
\end{tabular}




\section{Analytical Framework and Estimation Method}

Depending on the field of specialization, different estimation methods have been employed in the literature investigating the determinants of happiness (Ferrer-i-carbonell \& Frijters, 2004; Kristoffersen, 2010). Generally, psychologists and sociologists prefer to employ Ordinary Least Squares (OLS) regressions, treating happiness as a cardinal variable. Economists, on the other hand, regard happiness as an ordinal variable and thus opt for ordered response models (van Praag, 2007). The preference of cardinality assumption by psychologists has been criticized by economists, arguing that the subjectivity of happiness hinders the assessment of the realism of the cardinality assumption (Ferrer-i-Carbonell and Frijters, 2004; MacKerron, 2012). Economists, by relaxing the assumption of cardinality, generally employ the standard ordered probit and logit models, which treat ordinal data as the discrete expression of a continuous latent variable of arbitrary scale (Blanchflower \& Oswald, 2004b). Yet results obtained using models that do and models that do not assume cardinality are usually extremely similar (MacKerron, 2012). There are empirical studies employing both methods in order to demonstrate that results are not biased by the particular technique used in the analysis (Stevenson \& Wolfers, 2009). The models which impose cardinality provide results similar to ordered ones such as logit and probit (Ferrier-i-Carbonell and Frijters, 2004; Blanchflower and Oswald, 2004b; MacKerron, 2012).

We employ the following model specification for the underlying relationship between selfrated happiness level and its determinants.

$$
H_{i}^{*}=X_{i} \beta+\alpha T_{i}+\varepsilon_{i 1}
$$

Where $\mathrm{X}_{\mathrm{i}=}\left(\mathrm{X}_{1 \mathrm{i}}, \mathrm{X}_{2 \mathrm{i}}, \ldots, \mathrm{X}_{\mathrm{ki}}\right)$ is a $\mathrm{k} \times 1$ vector of covariates, $\left(\beta_{1}, \beta_{2}, \ldots, \beta_{\mathrm{k}}\right)$ is a vector of parameters to be estimated, $\mathrm{H}_{\mathrm{i}}$ is the happiness level of the respondent $\mathrm{i} ; \mathrm{T}_{\mathrm{i}}$ is the terrorism index for the region/city in which the respondent lives and $\varepsilon_{i 1}$ is normally distributed error term. 
Although $H_{i}^{*}$ cannot be observed, a discrete ordered categorical variable $\mathrm{H}$ is observed. The relationship between $H_{i}$ and $H_{i}^{*}$ can be represented as follows

$$
\begin{gathered}
H_{i}=1 \quad \text { if } H_{i}^{*} \leq \mu_{1} \\
H_{i}=2 \quad \text { if } \mu_{1}<H_{i}^{*} \leq \mu_{2} \\
H_{i}=3 \quad \text { if } \mu_{2}<H_{i}^{*} \leq \mu_{3} \\
H_{i}=4 \quad \text { if } \mu_{3}<H_{i}^{*} \leq \mu_{4} \\
H_{i}=5 \quad \text { if } H_{i}^{*}>\mu_{4}
\end{gathered}
$$

Where $\mu_{\mathrm{i}}(\mathrm{i}=1,2,3,4)$ are free parameters that represent the threshold values of the model, that bound the categories into which $H_{i}^{*}$ falls. Since we observe levels of self-rated happiness as a categorical variable, we utilize ordered probit models for empirical estimation. All models are estimated with heteroscedasticity-consistent standard errors.

The models are intended to be estimated primarily by ordered probit to account for the ordinal comparability in rated happiness. However, to address the issue of endogeneity of income in determination of happiness and interdependence leading to unobserved heterogeneities, a conditional mixed process model has been employed where the correlation between the error terms of happiness and income is estimated as an auxiliary parameter. The conditional mixed process estimator (CMP) is an alternative which is more suitable for multiple equations estimations involving different types of dependent and independent variables (Roodman, 2011). It enables researchers to jointly estimate the system of reduced and structural equations.

Our model is a simultaneous equation system with two equations where model equations can have different dependent variables.

$$
\begin{aligned}
& H_{i}^{*}=X_{i} \beta+\alpha T_{i}+\varepsilon_{i 1} \\
& I G_{i}=X_{i} \lambda+\varepsilon_{i 2}
\end{aligned}
$$

where $\mathrm{H}$ denotes ordinal variable of happiness ranging from 1 completely unhappy to 5 completely happy; IG denotes income group ranging from 1 ( 0 - 350 USD) to 5 (over 2950 USD), and the error terms are assumed to be bivariate normally distributed with zero mean, unit variance and correlation coefficient $\rho . X_{i}=\left(X_{1 i}, X_{2 i}, \ldots, X_{k i}\right)$ is a $\mathrm{k} \times 1$ vector of covariates, $\mathrm{T}_{\mathrm{i}}$ is average terrorism variable, $\left(\beta_{1}, \beta_{2}, \ldots, \beta_{k}\right)$ and $\left(\lambda_{1}, \lambda_{2}, \ldots ., \lambda_{k}\right)$ are vectors of parameters to be estimated. 
The correlation between the error terms of two equations would capture the interdependence of unobserved components in subjective life satisfaction and income. If error terms of both equations are affected by similar components, they will not be independent, leading to inconsistent parameter estimates in univariate models. The Wald test, and / or Lagrange Multiplier Test provide evidence on the correlation between unobserved explanatory variables that affect both equations. A conditional maximum likelihood estimation approach, which imposes appropriate restrictions on the correlation structure between the errors of the two equations, can be employed to attain consistent and efficient estimates. Roodman's (2009, 2011) novel mixed-process model deals with the endogeneity problem and obtain efficient estimates. Roodman (2011) proposes a general tool implemented on Stata software and using the CMP algorithm to estimate a limited information maximum likelihood.

\section{Estimation Results}

Within constraints of the available data, we follow the literature and firstly estimate equation (1) to investigate the impact of terrorism on happiness in Turkey. The dependent variable is self-rated happiness and the main explanatory variable is the terrorism index of each province. ${ }^{4}$ The remaining explanatory variables are gender, age, education level, household income, perceived relative income, marital status, health indicator, work status and immigration status.

The single equation ordered probit estimation results for equation (1) are presented in Table 3. Empirical results reveal that average terrorism hinders self-reported happiness in Turkey. Females are significantly happier than males. There is a U-shaped relationship between age and self-reported happiness. As the level of education increases, people feel less happy. Marriage enhances self-reported happiness levels. With respect to work status, compared to an employed person, unemployed, retired and permanently disabled people tend to be less happy. Students and housekeepers are more likely to be happy compared to employed people. Migration also has a positive impact on self-reported happiness. Both household income level and perceived income foster happiness.

\footnotetext{
${ }^{4}$ Alternative specifications for terrorism variable have also been considered. We have estimated models using average of terrorism index for 2000-2013 to examine the cumulative effect and models with the lagged values of terrorism index. The estimation results remained robust when alternative definitions of terrorism variable have been used.
} 
Table 3. Ordered Probit Single Equation Estimates

\begin{tabular}{|c|c|}
\hline VARIABLES & Happiness \\
\hline \multirow[t]{2}{*}{ Terrorism Index } & $-0.021 * * *$ \\
\hline & $(0.000)$ \\
\hline \multirow[t]{2}{*}{ Gender } & $0.054 * * *$ \\
\hline & $(0.01)$ \\
\hline \multirow[t]{2}{*}{ Age } & $-0.045 * * *$ \\
\hline & $(0.000)$ \\
\hline \multirow[t]{2}{*}{ Age Square } & $0.0005 * * *$ \\
\hline & $(0.000)$ \\
\hline \multirow[t]{2}{*}{ Primary School } & $-0.0195^{* *}$ \\
\hline & $(0.015)$ \\
\hline \multirow[t]{2}{*}{ High School } & $-0.072 * * *$ \\
\hline & $(0.000)$ \\
\hline \multirow[t]{2}{*}{ University and Higher Education } & $-0.119 * * *$ \\
\hline & $(0.000)$ \\
\hline \multirow[t]{2}{*}{ Household Income Level } & $0.057 * * *$ \\
\hline & $(0.000)$ \\
\hline \multirow[t]{2}{*}{ Perceived Relative Income } & $0.128 * * *$ \\
\hline & $(0.000)$ \\
\hline \multirow[t]{2}{*}{ Married } & $0.327 * * *$ \\
\hline & $(0.00)$ \\
\hline \multirow[t]{2}{*}{ Unhealthy } & $-0.237 * * *$ \\
\hline & $(0.00)$ \\
\hline \multirow[t]{2}{*}{ Unemployed } & $-0.334 * * *$ \\
\hline & $(0.000)$ \\
\hline \multirow[t]{2}{*}{ Retired } & $0.036 * * *$ \\
\hline & $(0.006)$ \\
\hline \multirow[t]{2}{*}{ Student } & $-0.085 * * *$ \\
\hline & $(0.000)$ \\
\hline \multirow{2}{*}{ House Keeping } & $0.0573 * * *$ \\
\hline & $(0.000)$ \\
\hline \multirow[t]{2}{*}{ Disabled } & $-0.206 * * *$ \\
\hline & $(0.000)$ \\
\hline \multirow[t]{2}{*}{ Immigrant } & $0.089 * * *$ \\
\hline & $(0.000)$ \\
\hline \multicolumn{2}{|c|}{ P-values in parentheses. $* * * \mathrm{p}<0.01, * * \mathrm{p}<0.05, * \mathrm{p}<0.1$} \\
\hline \multicolumn{2}{|l|}{ LR: $\chi^{2}(17)=16035.32$} \\
\hline \multicolumn{2}{|l|}{ Prob $>\chi^{2}=0.0000$} \\
\hline \multicolumn{2}{|l|}{ Pseudo $\mathrm{R}^{2}=0.0501$} \\
\hline
\end{tabular}

As self-ratings of individual's overall life satisfaction are measured by an ordered categorical variable, existing studies have generally employed single equation standard ordered response models to analyze determinants of subjective well-being. Since these studies consider various forms of subjective well-being and income level as independent achievements or choices, they fail to account for any interdependency among these variables. There is extensive evidence provided by cross-sectional and panel survey data studies which suggest that higher 
income is associated with elevated levels of satisfaction with life (Blanchflower \& Oswald, 2004a; Diener, Diener, \& Diener, 1995; Ferrer-i-Carbonell \& Frijters, 2004; Frijters, Haisken-denew, \& Shields, 2004; Kahneman et al., 2006; Stevenson \& Wolfers, 2009). On the other hand, Easterlin's pioneering study shows that, on average, people with higher income are happier. However, raising income of all individuals does not increase happiness level for all of them. Hence, Easterlin Paradox suggests that increasing income should not necessarily lead to an increase in happiness since individual's income in comparison to others' income has not changed (Easterlin, 1974, 1995, 2001). Thus, only the relative income is significant for life satisfaction (Clark, Frijters, \& Shields, 2006; Mentzakis \& Moro, 2009). These mixed findings pave the way for further research on income-happiness relation. ${ }^{5}$

The random disturbances that affect various forms of subjective well-being such as happiness, life satisfaction and income level may be correlated. Thus, happiness and income levels may be interdependent. Neglecting this unobserved heterogeneity will result in personality bias on the obtained estimates. ${ }^{6}$ Earlier studies reveal that happy people are more likely to have a number of positive psychological traits. Thus, they are more productive and successful in their professions leading to improved workplace outcomes and higher satisfaction levels with their jobs compared to unhappy people (Boehm \& Lyubomirsky, 2008; Judge \& Ilies, 2004; Mignonac \& Herrbach, 2005). Moreover individual characteristics have an impact on both subjective well-being and income determination. Individuals who are extravert and resilient are more likely to be happy and earn more (Boehm \& Lyubomirsky, 2008; Lyubomirsky, King, \& Diener, 2005). Furthermore, individuals may need to work in unfavourable conditions, long hours and spend time away from their homes and loved ones, all of which negatively affect their subjective well-being. In such a case, estimating standard ordered response models would inappropriately constrain the correlation between the random disturbances to be equal to zero, implying that any randomness affecting the subjective wellbeing is unrelated to the income level. This constraint can be relaxed by jointly estimating the equations in the form of a bivariate ordered response model, which contains an extra parameter to account for the correlation across equations in the same sense as a seemingly unrelated regression model.

The empirical results of the conditional mixed effect estimation for two-equation system in Equation (2) are presented in Table 4, where the dependent variables are self-rated happiness and income level, respectively. The conditional mixed process estimation results reveal that

\footnotetext{
${ }^{5}$ Please see Frey and Stutzer (2002) for a detailed literature review of economics and happiness.

${ }^{6}$ Please see (Powdthavee, 2010) for a review.
} 
the correlation coefficient between the disturbances of the two equations (atanhrho) is statistically significant, indicating that single equation ordered probit estimates fail to capture the association of life satisfaction and income level. A statistically significant positive value of the correlation coefficient (atanhrho) suggests that happiness and income are directly associated.

The estimation results for the happiness equation presented in Table 4 are quite similar to the single equation model. Terrorism has a statistically significant negative impact on happiness, supporting the earlier evidence provided by (Frey et al., 2007; Vorsina et al., 2015). The great majority of the existing research reports a positive association between absolute income and happiness or subjective well-being, though its impact is smaller compared to variables such as marriage and unemployment (Ferrer-i-Carbonell, 2013). Yet, the empirical evidence regarding the relation between happiness and relative income is mixed (Verme, 2013).

A strand of the literature using panel data for developed countries report a negative relation between self-reported happiness and income of the reference group (Helliwell, 2003; Stutzer, 2004; Vendrik \& Woltjer, 2007). Whereas a positive association between perceived income and happiness is reported for a number of less developed countries (Dumludag, Gokdemir, \& Giray, 2016; Knight, Song, \& Gunatilaka (2007); Knight, Shi, \& Song, 2004; Stutzer, 2004). Results presented in Tables 3 and 4 reveal that level of perceived relative income has a positive impact on self-reported happiness in Turkey. Individuals are happier when their income is higher than the income of the reference group. This results is consistent with previous findings for Turkey reported by Dumludag et al. (2016).

The single equation estimation results of Table 3 reveal that increases in education level hinder happiness. According to results presented in Table 4, however, education variables are not statistically significant when the endogeneity of income group variable has been taken into account. Previous studies report mixed results for the relationship between education level and life satisfaction. While Dumludag (2013) and Kangal (2013) find a positive education effect, Selim (2008) reports that education is not a statistically significant determinant of happiness. Recently, Dumludag et al. (2016) provide empirical evidence for the U-shaped relationship between education and happiness. The endogeneity of income could be one of the reasons of mixed empirical findings with respect to education variable. Even though education may have an impact on happiness, it is not a direct effect. Rather, education fosters happiness indirectly through its positive effects on income level. The empirical results of CMP estimation of the income equation, presented in Table 4 suggest that higher levels of education lead to an increase in income which then enhances individuals' 
happiness. This could be due to the fact that enhancing human capital enables people to get better jobs with higher earnings.

Existing empirical research confess that absolute income enhances happiness and its marginal impact on self-reported happiness decreases when individual income increases. In addition to this direct effect, income also affects happiness through social comparisons with certain reference groups (Clark, Frijters, \& Shields, 2008; Dumludag et al., 2016; Wolbring, Keuschnigg, \& Negele, 2013).

With respect to socio-demographic variables, our results indicate that self-reported happiness follows a U-shape over age which is consistent with the existing literature (Blanchflower \& Oswald, 2008; Cheng, Powdthavee, \& Oswald, 2015; Landeghem, 2008; Stone, Schwartz, Broderick, \& Deaton, 2010). For Turkey, the literature either reports a negative (Ekici \& Koydemir, 2014; Selim, 2008) or a U-shaped (Caner, 2014; Dumludag et al., 2016) impact of age on happiness. Empirical findings of our study indicate that happiness falls and reaches a minimum at age 51, which is very close to age 55 reported in the literature and then rises again (Blanchflower \& Oswald, 2004a; Frijters \& Beatton, 2012). Gender differences in happiness exist and our estimation results imply that females are happier than males. This finding is consistent with previous evidence (Caner, 2014; Cordero, Salinas-Jiménez, \& Salinas-Jiménez, 2017; Ekici \& Koydemir, 2014; Selim, 2008). Being married enhances the likelihood of being happy supporting the earlier findings (Dumludag et al., 2016; Ekici \& Koydemir, 2014; Mentzakis \& Moro, 2009; Stutzer \& Frey, 2006). Stack \& Eshleman (1998) suggest three intermediating processes through which marriage or cohabitation may positively impact happiness: marriage may enhance financial resources, stimulate better physical health and yield greater emotional support. Stutzer \& Frey (2006), on the other hand, claim that happier people are more likely to get married; hence there is a bidirectional relationship between them.

Considering the work status, being unemployed or disabled hinders happiness. However, retirees and house keepers are more likely to be happy compared to employed individuals. Employment is generally considered to provide basic financial resources, social contacts, a social status and identity within society's institutions and networks (van der Meer, 2014; Warr, 1982). Thus, unemployment is expected to be negatively related with happiness, which is empirically supported by both longitudinal and cross-sectional research (Ferrer-i-Carbonell \& Frijters, 2004; Stam, Sieben, Verbakel, \& de Graaf, 2016; Winkelmann \& Winkelmann, 1998).When unemployed, an individual loses both financial and social benefits. Winkelmann and Winkelmann (1998) argue that non-pecuniary costs of unemployment are greater than the 
pecuniary costs resulting from loss of income. The loss of financial resources during unemployment may refrain people from planning their future and fulfilling various psychological needs; and it may even lead to poverty (Shields \& Price, 2005). The loss of non-pecuniary benefits, on the other hand, may lead to social exclusion. These loses of nonpecuniary benefits may explain the happiness levels of individuals who belong to other work / employment status, such as retirees, housekeepers, disabled people and students (Stam et al., 2016). ${ }^{7}$ The ability to compensate for the lack of non-pecuniary benefits determines the degree of well-being. Hence, homemakers are expected to follow employed people in terms of happiness as family sphere may reward the lost non-pecuniary benefits. Students also have a social environment and they can create identities and activities that compensate the lost benefits (Calvo, Mair, \& Sarkisian, 2015). Similarly, retirees may also benefit from a family environment, which makes up the lost benefits of employment. On the other hand, unemployed and disabled may have some difficulties compensating for the lack of nonpecuniary benefits through other activities (Stam et al., 2016; Strandh, Hammarström, Nilsson, Nordenmark, \& Russel, 2013). Thus, empirical results provided in Table 4 are in line with the existing literature, except for students. Being a student hinders happiness in Turkey.

The accumulated evidence indicates that the better the individual's both physical and psychological health, the happier (s)he is on average. ${ }^{8}$ Bloom \& Canning (2000) argue that there is two-way causality between health and income. Healthy people tend to be more productive; more likely to invest in human capital, hence they are more educated. Additionally, since they are more likely to live longer they tend to invest in physical capital. Accordingly, any improvement in health status elevates happiness. Moreover, chronic diseases and specific conditions, such as heart attacks and strokes reduce satisfaction with life (Dolan, Peasgood \& White, 2008). Our findings are in line with the previous literature that being unhealthy in the previous year reduces happiness (Dumludag, 2013; Peiró, 2006; Selim, 2008; Stam et al., 2016).

Considering only economic motives for migration, one may assume that life in wealthier countries/provinces bring more happiness and prosperity. However, the bulk of evidence in the literature generally suggests that migrants are less happy than natives in destination countries even though there has been a rise in their income levels (Bălţătescu, 2007;

\footnotetext{
${ }^{7}$ Please see Stam et al. (2016) and Calvo, Mair, \& Sarkisian (2015) for a detailed discussion on how work status and subjective wellbeing is associated.

${ }^{8}$ Please see (Frey \& Stutzer, 2002) for a review.
} 
Bartram, 2013; Knight \& Gunatilaka, 2010; Kóczán, 2016). Several factors may contribute to this finding, such as underemployment and social factors such as discrimination, extended separation from close family, and isolation (Bartram, 2013). Similar findings are reported in research on internal migration for China (Knight \& Gunatilaka, 2010); for Thailand (Jong, Chamratrithirong, \& Tran, 2002), for Germany (Nakazato, Schimmack, \& Oishi, 2011) and for Britain (Nowok, van Ham, Findlay, \& Gayle, 2013). The empirical findings of this study suggest that immigrants are more likely to be happy compared to natives in Turkey, supporting the findings of Melzer (2011) and Switek (2016) though there appears to be decline in their household income. Melzer (2011) finds that migrants, moving from East to West Germany, have improved their life satisfaction levels. Switek (2016), on the other hand, states that the migration's impact on happiness depends on the reason for move, and only individuals migrated for better employment opportunities experience an increase in life satisfaction which lasts 6-10 years after their move. Both papers focus on more homogenous groups of migrants, which could be the case for Turkey as well. Our finding that internal migration reduces income is in line with Tunalı (2000) who reports that nearly $75 \%$ of migrants in Turkey realizes net negative monetary returns over the period 1963-1973.

When the remaining variables for Income Level equations are considered, it appears that as number of females, number of disabled, and number of students in the household increases, there is a decline in the household income level. However, an increase in number of income earners would lead to a rise in income level of the household. 
Table 4. CMP Estimation Results

\begin{tabular}{|c|c|c|}
\hline VARIABLES & Happiness & Income level \\
\hline \multirow[t]{2}{*}{ Terrorism Index } & $-0.021 * * *$ & \\
\hline & $(0.000)$ & \\
\hline \multirow[t]{2}{*}{ Gender } & $0.054 * * *$ & \\
\hline & $(0.000)$ & \\
\hline \multirow[t]{2}{*}{ Age } & $-0.046^{* * *}$ & $0.0537 * * *$ \\
\hline & $(0.000)$ & $(0.000)$ \\
\hline \multirow[t]{2}{*}{ Age Square } & $0.0004 * * *$ & $-0.0005 * * *$ \\
\hline & $(0.00)$ & $(0.000)$ \\
\hline \multirow{2}{*}{ Primary School } & 0.003 & $0.566^{* * *}$ \\
\hline & $(0.703)$ & $(0.000)$ \\
\hline \multirow[t]{2}{*}{ High School } & -0.0002 & $1.384 * * *$ \\
\hline & $(0.988)$ & $(0.000)$ \\
\hline \multirow[t]{2}{*}{ University and Higher Education } & 0.0184 & $2.345 * * *$ \\
\hline & $(0.344)$ & $(0.000)$ \\
\hline \multirow[t]{2}{*}{ Perceived Relative Income } & $0.127 * * *$ & \\
\hline & $(0.000)$ & \\
\hline \multirow{2}{*}{ Married } & $0.321 * * *$ & \\
\hline & $(0.000)$ & \\
\hline \multirow[t]{2}{*}{ Unhealthy } & $-0.237 * * *$ & \\
\hline & $(0.000)$ & \\
\hline \multirow[t]{2}{*}{ Unemployed } & $-0.333 * * *$ & \\
\hline & $(0.000)$ & \\
\hline \multirow[t]{2}{*}{ Retired } & $0.044 * * *$ & \\
\hline & $(0.001)$ & \\
\hline \multirow[t]{2}{*}{ Student } & $-0.0762 * * *$ & \\
\hline & $(0.001)$ & \\
\hline \multirow[t]{2}{*}{ House Keeping } & $0.0538 * * *$ & \\
\hline & $(0.000)$ & \\
\hline \multirow[t]{2}{*}{ Disabled } & $-0.225 * * *$ & \\
\hline & $(0.000)$ & \\
\hline \multirow[t]{2}{*}{ Immigrant } & $0.080 * * *$ & $-0.120 * * *$ \\
\hline & $(0.000)$ & $(0.000)$ \\
\hline \multirow[t]{2}{*}{ Number of females } & & $-0.200 * * *$ \\
\hline & & $(0.000)$ \\
\hline \multirow[t]{2}{*}{ Number of disabled in the household } & & $-0.453 * * *$ \\
\hline & & $(0.000)$ \\
\hline \multirow[t]{2}{*}{ Number of students in the household } & & $-0.183 * * *$ \\
\hline & & $(0.000)$ \\
\hline \multirow[t]{2}{*}{ Number of income earners in the household } & & $0.761 * * *$ \\
\hline & & $(0.000)$ \\
\hline \multirow[t]{2}{*}{ atanhrho } & \multicolumn{2}{|c|}{$0.0803 * * *$} \\
\hline & \multicolumn{2}{|c|}{$(0.00)$} \\
\hline \multirow[t]{2}{*}{ Wald: $\chi^{2}$} & \multicolumn{2}{|c|}{ Wald: $\chi^{2}(16)=11758.38$} \\
\hline & Prob $>\chi^{2}=0.00$ & \\
\hline Log pseudolikelihood & -383029.76 & \\
\hline
\end{tabular}




\section{Conclusion}

Terrorism can be classified as a subset of human-caused disasters (Colletta, 2004; Goldfrank, Panzer and Butler, 2003) which in addition to causing material damage, can have a particularly devastating impact on psychological functioning. Goldfrank, Panzer and Butler (2003) state that terrorism may have a greater impact than other disasters on distress responses, behavioral change, and psychiatric illness due to the unique characteristics of terrorism events. Previous empirical evidence suggests that terrorism has economic, psychological, and social consequences. The economic costs of terrorism have been welldocumented in the literature. Yet, empirical evidence for the welfare costs is limited. This study investigates the impact of terrorism on self-reported happiness for Turkey, which has been suffering from terrorist activities for almost fifty years. Although previously terrorist activities have been localized in South Eastern provinces and major cities, the frequency and severity of attacks have been increasing. In addition to claiming many lives and damaging property, terrorism spreads fear, uncertainty, anxiety and anger, which collectively lead to changes in daily activities of people because of the unpredictability of such attacks. Understanding the extend of the welfare impacts of terrorism is crucial and may shape efforts to develop intervention strategies in order to lessen the adverse psychological effects of terrorism.

Employing a unique dataset which combines micro-data at individual level and macro-data at provincial level for Turkey, this article makes two major contributions to the literature. This study is the first to analyze the impact of terrorism on self-reported happiness in Turkey. Secondly, it contributes to happiness literature by jointly estimating self-reported happiness and income group variables, taking the possible endogeneity of the latter into account. For this purpose, it employs conditional mixed process estimation method, where the correlation between error terms of happiness and income models is estimated as an auxiliary parameter.

Empirical findings suggest that terrorism hinders self-reported happiness, supporting the findings of Frey, Luechinger and Stutzer (2007), Romanov, Zussman and Zussman (2012) and Vorsina et al. (2015). Furthermore, results indicate that there is a U-shaped relationship between age and self-reported happiness, while marriage, being female and being healthy enhance self-reported happiness levels. Though the single equation estimation results reveal that increases in education level hinder happiness, education variables are not statistically significant when the endogeneity of income has been taken into account. This finding 
suggests that education fosters happiness indirectly through its positive effects on income level. Regarding the work status, unemployed or disabled people are less happy compared to employed respondents. While migration elevates happiness, this is achieved at the expense of a lower household income. Regarding the determinants of income level, it appears that as number of females, number of disabled, and number of students in the household increases, there is a decline in the household income level. However, an increase in number of income earners would lead to a rise in income level of the household. Finally, the conditional mixed process estimation results reveal that the correlation coefficient between the disturbances of income and happiness models is statistically significant and positive. This result implies that any increase in income level enhances self-reported happiness. In addition to absolute level of household income, perceived relative income level is also positively related to life satisfaction of Turkish individuals.

In all, this study reveals that the true costs of terrorism include both tangible and intangible costs. The results suggest that the welfare costs of terrorism would be underestimated if it considers only the traditional economic costs. 


\section{References}

Araz-Takay, B., Arin, K. P., \& Omay, T. (2009). The Endogenous and Non-Linear Relationship Between Terrorism and Economic Performance: Turkish Evidence. Defence and Peace Economics, 20(1), 1-10.

Bălţătescu, S. (2007). Central and Eastern Europeans Migrants' Subjective Quality of Life. A Comparative Study. Journal of Identity and Migration Studies, 1(2), 67-81.

Bartram, D. (2013). Happiness and "economic migration": A comparison of Eastern European migrants and stayers. Migration Studies, 1(2), 156-175.

Bilgel, F., \& Karahasan, B. C. (2013). "The Economic Costs of Separatist Terrorism in Turkey ." Journal of Conflict Resolution, 1-23.

Blanchflower, D. G., \& Oswald, A. J. (2004a). Money, sex and happiness: An empirical study. Scandinavian Journal of Economics, 106(3), 393-415.

Blanchflower, D. G., \& Oswald, A. J. (2004b). Well-Being Over Time in Britain and the USA. Journal of Public Economics, 88(7), 1359-1386.

Blanchflower, D. G., \& Oswald, A. J. (2008). Is well-being U-shaped over the life cycle? Social Science and Medicine, 66(8), 1733-1749.

Bloom, D. E., \& Canning, D. (2000). The Health and Wealth of Nations. Science, 287(5456), 1207-1209.

Blunk, S. S., Clark, D. E., \& McGibany, J. M. (2006). Evaluating the long-run impacts of the 9/11 terrorist attacks on US domestic airline travel. Applied Economics, 38(4), 363-370.

Boehm, J. K., \& Lyubomirsky, S. (2008). Does Happiness Promote Career Success? Journal of Career Assessment, 16(1), 101-116. 
Brian W. Sloboda. (2003). Assessing the effects of terrorism on tourism by use of time series methods. Tourism Economics, 9(2), 179-190.

Calvo, E., Mair, C. A., \& Sarkisian, N. (2015). Individual troubles, shared troubles: The multiplicative effect of individual and country-level unemployment on life satisfaction in 95 nations (1981-2009). Social Forces, 93(4), 1625-1653.

Caner, A. (2014). Happiness, Comparison Effects, and Expectations in Turkey. Journal of Happiness Studies, 16(5), 1323-1345.

Canetti-Nisim, D., Halperin, E., Sharvit, K., \& Hobfoll, S. E. (2009). A new stress-based model of political extremism. Journal of Conflict Resolution, 53(3), 363-389.

Cheng, T. C., Powdthavee, N., \& Oswald, A. J. (2015). Longitudinal Evidence for a Midlife Nadir in Human Well-being: Results from Four Data Sets. Economic Journal, 1-17.

Clark, A. E., Frijters, P., \& Shields, M. A. (2006). Income and Happiness : Evidence, Explanations and Economic Implications. English, 78, 1-62.

Clark, A. E., Frijters, P., \& Shields, M. A. (2008). Relative income, happiness, and utility: An explanation for the Easterlin paradox and other puzzles. Journal of Economic Literature, $46(1), 95-144$.

Colletta, N. J. (2004). Human-Driven Disasters Violent Conflict, Terrorism and Technology. Inter-American Development Bank. Retrieved from http://www.iadb.org/wmsfiles/products/publications/documents/1442046.pdf.

Cordero, J. M., Salinas-Jiménez, J., \& Salinas-Jiménez, M. M. (2017). Exploring factors affecting the level of happiness across countries: A conditional robust nonparametric frontier analysis. European Journal of Operational Research, 256(2), 663-672.

Diener, E., Diener, M., \& Diener, C. (1995). Factors predicting the subjective well-being of nations. Journal of Personality and Social Psychology, 69(5), 851-64. 
Dolan, P., Peasgood, T., \& White, M. (2008). Do we really know what makes us happy? A review of the economic literature on the factors associated with subjective well-being. Journal of Economic Psychology, 29(1), 94-122.

Drakos, K., \& Kutan, A. M. (2003). Regional Effects of Terrorism on Tourism in Three Mediterranean Countries. The Journal of Conflict Resolution, 47(5), 621-641.

Dumludag, D. (2013). Life Satisfaction and Income Comparison Effects in Turkey. Social Indicators Research, 114(3), 1199-1210.

Dumludag, D., Gokdemir, O., \& Giray, S. (2016). Income comparison, collectivism and life satisfaction in Turkey. Quality and Quantity, 50(3), 955-980.

Easterlin, R. A. (1974). Does rapid economic growth improve the human lot? Some empirical evidence. In Nations and Households in Economic Growth: Essays in Honor of Moses Abramowitz, 89, 89-125.

Easterlin, R. A. (1995). Will raising the incomes of all increase the happiness of all? Journal of Economic Behavior and Organization, 27(1), 35-47.

Easterlin, R. A. (2001). Income and Happiness : Towards a Unified Theory. Nations and Households in Economic Growth: Essays in Honor of Moses Abramowitz, 111(473), $465-484$.

Eckstein, Z., \& Tsiddon, D. (2004). Macroeconomic consequences of terror: theory and the case of Israel. Journal of Monetary Economics, 51(5), 971-1002.

Ekici, T., \& Koydemir, S. (2014). Social Capital, Government and Democracy Satisfaction, and Happiness in Turkey: A Comparison of Surveys in 1999 and 2008. Social Indicators Research, 118(3), 1031-1053.

Enders, W., \& Sandler, T. (1991). Causality between transnational terrorism and tourism: The case of Spain. Studies in Conflict \& Terrorism, 14(1), 49-58. 
Enders, W. \& Sandler, T. (1993). The Effectiveness of Antiterrorism Policies: A VectorAutoregression- Intervention Analysis. The American Political Science Review, 87(4), 829-844.

Enders, W. \& Sandler, T. (2000). Is Transnational Terrorism Becoming More Threatening? A time-series investigation. Journal of Conflict Resolution, 44(3), 307-322.

Enders, W., Sandler, T., \& Parise, G. F. (1992). An Econometric Analysis of the Impact of Terrorism on Tourism. Kyklos, 45(4), 531-554.

Feridun, M., \& Sezgin, S. (2008). Regional Underdevelopment and Terrorism: the Case of South Eastern Turkey. Defence and Peace Economics, 19(3), 225-233.

Ferrer-i-Carbonell, A. (2013). Happiness economics. SERIEs, 4(1), 35-60.

Ferrer-i-Carbonell, A., \& Frijters, P. (2004). How Important is Methodology for the Estimate of the Determinants of Hapiness? The Economic Journal, 114(497), 641-659.

Fielding, D. (2003). Counting the cost of the Intifada: Consumption, saving and political instability in Israel. Public Choice, 116(3-4), 297-312.

Fielding, D. (2004). How Does Violent Conflict Affect Investment Location Decisions? Evidence from Israel during the Intifada. Journal of Peace Research, 41(4), 465-484.

Frey, B. S., Luechinger, S., \& Stutzer, A. (2007). Calculating strategy: Assessing the costs of terrorism. Journal of Economic Surveys, 21(1), 1-24.

Frey, B. S., Luechinger, S., \& Stutzer, A. (2009). The life satisfaction approach to valuing public goods: The case of terrorism. Public Choice, 138(3-4), 317-345.

Frey, B. S., \& Stutzer, A. (2002). What Can Economists Learn from Happiness Research? Journal of Economic Literature, 40(2), 402-435.

Frijters, B. P., Haisken-denew, J. P., \& Shields, M. A. (2004). Money Does Matter ! Evidence 
from Increasing Real Income and Life Satisfaction in East Germany Following Reunification. The American Economic Review, 94(3), 730-740.

Frijters, B.P., \& Beatton, T. (2012). The mystery of the U-shaped relationship between happiness and age. Journal of Economic Behavior and Organization, 82(2-3), 525-542.

Goldfrank, L. R., Panzer, A. M., \& Butler, A. S. (Eds.). (2003). Preparing for the psychological consequences of terrorism: A public health strategy. National Academies Press.

Greenbaum, R. T., Dugan, L., \& Lafree, G. (2006). The Impact of Terrorism on Italian Employment and Business Activity, 44, 1093-1108.

Helliwell, J. F. (2003). How's life? Combining individual and national variables to explain subjective well-being. Economic modelling, 20(2), 331-360.

Jong, G. F., Chamratrithirong, A., \& Tran, Q. G. (2002). For Better, For Worse: Life Satisfaction Consequences of Migration. International Migration Review, 36(3), 838863.

Judge, T. A., \& Ilies, R. (2004). Is positiveness in organizations always desirable?. The Academy of Management Executive, 18(4), 151-155.

Kahneman, D., Kahneman, D., Krueger, A. B., Schkade, D., Schwarz, N., \& Stone, A. A. (2006). Would You Be Happier If You Were. Science, 312, 1908-1910.

Kangal, A. (2013). Mutluluk Üzerine Kavramsal Bir Değerlendirme ve Türk Hanehalkı için Bazı Sonuçlar. Elektronik Sosyal Bilimler Dergisi, 12(44), 214-233.

Knight, J., \& Gunatilaka, R. (2010). Great Expectations? The Subjective Well-being of Rural-Urban Migrants in China. World Development, 38(1), 113-124.

Knight, J., Shi, L., \& Song, L. (2004). The Rural-Urban Divide and the Evolution of Political Economy in China. Human development in the era of globalization: Essays in honor of 
Keith B. Griffin, 44, Retrieved from:

http://books.google.com/books?hl=en\&lr=\&id=tdAAR0KIydgC\&oi=fnd\&pg=PA44\&d $\mathrm{q}=$ The + Political+Economy + of + China's + Rural-Urban+Divide\&ots=rfHwzMqHG\&sig=hyrD1dB6yxK5bHMoital0uT0Yrs

Knight, J., Song, L. and Gunatilaka, R. (2007). Subjective Well-Being and Its Determinants in Rural china. China Economic Review, 20(4), 635-649.

Kóczán, Z. (2016). (Why) are immigrants unhappy. IZA Journal of Migration, 5:3, 25.

Kristoffersen, I. (2010). The metrics of subjective wellbeing: Cardinality, Neutrality and Additivity. Economic Record, 86(272), 98-123.

Landeghem, B. G. M. Van. (2008). Longitudinal Evidence from a 20-Year Panel Human Well-Being over the Life Cycle: Longitudinal Evidence from a 20-Year Panel. Journal of Economic Behavior \& Organization, 81(2), 571-582.

Lyubomirsky, S., King, L., \& Diener, E. (2005). The benefits of frequent positive affect: Does happiness lead to success? Psychological Bulletin, 131(6), 803-855.

MacKerron, G. (2012). Happiness Economics From 35000 Feet. Journal of Economic Surveys, 26, 705-735.

Melzer, S. M. (2011). Does Migration Make You Happy? The Influence of Migration on Subjective Well-Being. Journal of Social Research \& Policy, 2(2), 73-92.

Mentzakis, E., \& Moro, M. (2009). The poor, the rich and the happy: Exploring the link between income and subjective well-being. Journal of Socio-Economics, 38(1), 147158.

Mignonac, K., \& Herrbach, O. (2005). Linking work events, affective states, and attitudes: An empirical study of managers' emotions. Journal of Business and Psychology, 19(2), $221-240$. 
Nakazato, N., Schimmack, U., \& Oishi, S. (2011). Effect of Changes in Living Conditions on Well-Being: A Prospective Top-Down Bottom-Up Model. Social Indicators Research, 100(1), 115-135.

Nowok, B., van Ham, M., Findlay, A. M., \& Gayle, V. (2013). Does migration make you happy? a longitudinal study of internal migration and subjective well-being. Environment and Planning A, 45(4), 986-1002.

Ocal, N., \& Yildirim, J. (2010). Regional effects of terrorism on economic growth in Turkey: A geographically weighted regression approach. Journal of Peace Research, 47(4).

Peiró, A. (2006). Happiness, satisfaction and socio-economic conditions: Some international evidence. Journal of Socio-Economics, 35(2), 348-365.

Powdthavee, N. (2010). How much does money really matter? Estimating the causal effects of income on happiness. Empirical Economics, 39(1), 77-92.

Romanov, D., Zussman, A., \& Zussman, N. (2012). Does Terrorism Demoralize? Evidence from Israel. Economica, 79(313), 183-198.

Roodman, D. (2009). Mixed-process models with cmp. CGD Working Paper, 168.

Roodman, D. (2011). Fitting fully observed recursive mixed-process models with cmp. Stata Journal, 11(2), 159-206.

Schiff, M. (2006). Living in the shadow of terrorism: Psychological distress and alcohol use among religious and non-religious adolescents in Jerusalem. Social Science and Medicine, 62(9), 2301-2312.

Schuster, M. A., Stein, B. D., Jaycox, L. H., Collins, R. L., Marshall, G. N., Elliott, M. N., \& Berry, S. H. (2001). A national survey of stress reactions after the September 11, 2001, terrorist attacks. New England Journal of Medicine, 345(20), 1507-1512.

Selim, S. (2008). Life satisfaction and happiness in Turkey. Social Indicators Research, 
$88(3), 531-562$.

Shalev, A. Y., Tuval, R., Frenkiel-Fishman, S., Hadar, H., \& Eth, S. (2006). Psychological responses to continuous terror: A study of two communities in Israel. American Journal of Psychiatry, 163(4), 667-673.

Shields, M.A. and Price, S. (2005). Exploring the Economic and Social Determinants of Psychological Well-Being and Perceived Social Support in England. Journal of the Royal Statistical Society. Series A (Statistics in Society), 168(3), 513-537.

Stack, S., \& Eshleman, J. R. (1998). Marital Status and Happiness : A 17-Nation Study. Journal of Marriage and Family, 60(2), 527-536.

Stam, K., Sieben, I., Verbakel, E., \& de Graaf, P. M. (2016). Employment status and subjective well-being: the role of the social norm to work. Work, Employment \& Society, 30(2), 309-333.

Stevenson, B. B., \& Wolfers, J. (2009). American Economic Association The Paradox of Declining Female Happiness, American Economic Journal : Economic Policy, 1(2), $190-225$.

Stone, A., Schwartz, J. E., Broderick, J. E., \& Deaton, A. (2010). A snapshot of the age distribution of psychological well-being in the United States. Proceedings of the National Academy of Sciences of the United States of America, 107(22), 9985-9990.

Strandh, M., Hammarström, A., Nilsson, K., Nordenmark, M., \& Russel, H. (2013). Unemployment, gender and mental health: The role of the gender regime. Sociology of Health and Illness, 35(5), 649-665.

Stutzer, A. (2004). The role of income aspirations in individual happiness. Journal of Economic Behavior \& Organization, 54(1), 89-109.

Stutzer, A., \& Frey, B. S. (2006). Does marriage make people happy, or do happy people get married? Journal of Socio-Economics, 35(2), 326-347. 
Switek, M. (2016). Internal Migration and Life Satisfaction: Well-Being Paths of Young Adult Migrants. Social Indicators Research, 125(1), 191-241.

Tosun, C., Timothy, D. J., \& Ozturk, Y. (2003). Tourism Growth, National Development and Regional Inequality in Turkey. Journal of Sustainable Tourism, 11(2-3), 133-161.

Tunal1, I. (2000). Rationality of Migration. International Economic Review, 41(4), 893-920.

Unal, M. C. (2016). Is it ripe yet? Resolving Turkey's 30 years of conflict with the PKK. Turkish Studies, 17(1), 91-125.

Van der Meer, P. H. (2014). Gender, Unemployment and Subjective Well-Being: Why Being Unemployed Is Worse for Men than for Women. Social Indicators Research, 115(1), 23-44.

Van Praag, B. M. S. (2007). Perspectives from the happiness literature and the role of new instruments for policy analysis. CESifo Economic Studies, 53(1), 42-68.

Vendrik, M. C. M., \& Woltjer, G. B. (2007). Happiness and loss aversion: Is utility concave or convex in relative income? Journal of Public Economics, 91(7-8), 1423-1448.

Verme, P. (2013). The Relative Income and Relative Deprivation Hypotheses: A Review of the Empirical Literature. Policy Research Working Papers, 34.

Vorsina, M., Manning, M., Fleming, C. M., Ambrey, C. L., \& Smith, C. (2015). The welfare cost of terrorism. Terrorism and Political Violence, 1-21.

Warr, P. (1982). Psychological aspects of employment and unemployment. Psychological Medicine, 12(1), 7-11.

Winkelmann, L. \& Winkelmann, R. (1998). Why are the Unemployed So Unhappy? Evidence from Panel Data. Economica, 65(257), 1-15.

Wolbring, T., Keuschnigg, M., \& Negele, E. (2013). Needs, comparisons, and adaptation: 
The importance of relative income for life satisfaction. European Sociological Review, 29(1), 86-104.

Yaya, M. E. (2009). Terrorism and Tourism: the Case of Turkey. Defence and Peace Economics, 20(6), 477-497.

Yechiam, E., Barron, G., Erev, I., Krakover, S., Busemeyer, J., \& Weinberg, I. (2005). The Role of Personal Experience in Contributing to Different Patterns of Response to Rare Terrorist Attacks. The Journal of Conflict Resolution, 49(3), 430-439.

Yildirim, J., \& Ocal, N. (2013). Analysing the Determinants of Terrorism in Turkey Using Geographically Weighted Regression. Defence and Peace Economics, 24(3), 195-209. 